\title{
Urgency of Strengthening the Role of Directorate of Special Crimes of Indonesian National Police in The Special Criminal Law Enforcement
}

\author{
Mangimpal Silaban ${ }^{1}$ \\ \{ silabanipal@gmail.com \} \\ ${ }^{1}$ Doctoral Students of Law Science of Jayabaya University, Indonesia
}

\begin{abstract}
The presence of ad hoc institutions in field of law enforcement such as Corruption Eradication Commission (KPK), Terrorism Prevention National Board (BNPT), and Narcotics National Board (BNN), within the last two decades has been unable to significantly reduce the number of special criminal actions that become the portion of the institutions. Optimal and surging simultaneous law enforcement strategies in all regions of Indonesia has to be immediately formulated and implemented as an anticipation from the increasing number of special criminal cases. The study used normative juridical method. The study reviewed that one of the resources that had an ability and network until district level (Sectoral Police) as the spearhead to prevent the increasing number of special criminal actions was the special criminal and detective range known as Special Crime under Crime and Detective Department of Indonesian National Police. The fact could not be denied in addition to the need of revision of laws related to special criminal actions reinforce Crime and Detective Department tactically and elegantly but effectively in prosecuting special criminal actions. The role reinforcement of Special Criminal Directorate of Indonesian National Police in Order of Criminal Law Enforcement in field of Special Criminal Actions to Maintain State Security and Sovereignty was by reformulation of its institutional and powers in order to maintain state security and sovereignty from Special Criminal Actions.
\end{abstract}

Keywords: Special Criminal Actions; Security; Sovereignty; Institutions

\section{Introduction}

The advent of ad hoc institutions in Indonesia, such as the Corruption Eradication Commission (KPK), the National Counter-Terrorism Agency (BNPT), the National Narcotics Board (BNN) in the law enforcement for the last two decades has proved incapable of significantly reducing the number of special crimes to which those institutions are specified [1] . Corruption crime with its transactional appearance is still massively committed and seems to be increasingly prevalent like a trivial exchange in a market; terrorism in many regions of Indonesia is increasing quantitatively and qualitatively. The last case, which took place in Jakarta on January 14, 2016, with a considerable number of victims, admittedly, is carved on the memories of many Indonesian People. Circulation of drug, its use, and the number of the couriers, continues to undergo a significant increase. The number of cases related to drugs from month to month continues to grow and involves various classes of society. 
The birth of those ad hoc institutions mentioned above has not been able to guarantee that the number of special crimes significantly decreases. Therefore, a simultaneous and optimal law enforcement strategy throughout the territory of Indonesia must be immediately formulated and carried out in anticipation of the growing number of special criminal cases mentioned above. One of the Indonesian resources that have the ability and the network up to the district level (Sectoral Police) to cope with the growth of special crimes mentioned above is the Investigators Line for Special Crime (known as "Krimsus") under the Criminal Investigation Agency (Bareskrim) of the Indonesian National Police. This fact shows that revision is necessary for the laws relating to special crimes to produce legislation that can strengthen the Criminal Investigation Agency so that the agency can effectively and elegantly tackle the special crimes mentioned above.

In other words, to strengthen the role of the Directorate of the Special Crimes in terms of the Special Criminal Law Enforcement for maintaining public order and national sovereignty is to reformulate the institution and its authority to safeguard the security and sovereignty of the State from Special Crimes.

Current development in various fields has resulted in many competitions in searching for benefits and profits by using any measures, including those that are breaking the prevailing laws. Crimes committed in the new types and models rise as if they adjust themselves with the current developments, which has not accommodated yet by the Indonesian Criminal Code (KUHP) that was made during Dutch colonialism. Those types of crime are known as "Special Crime," or special criminal act.

\section{Methods}

This research used a juridical normative research method (legal research), which is descriptive and aims to describe the research qualitatively. The secondary data used in this research is collected from (a) primary legal materials in the forms of legislation related to the research theme, and (b) secondary legal materials in the forms of books and journals related to this research theme and further elaboration of the primary legal materials into theoretical contexts.

The use of the normative juridical method was designed to answer the urgency of strengthening the role of Directorate of Special Crimes of Indonesian National Police in the special criminal law enforcement for the sake of sustaining State Security and Sovereignty.

\section{Result and Discussion}

\subsection{Directorate of Special Crimes Position.}

The bureaucratic reform in the government demands the enhancement of the Indonesian National Police professionalism, so too with the Directorate of Special Crimes that are developed and coached by referring to the motto "Sidik Sakti Indra Waspada." The Directorate of Special Crimes was established in 2002 as a part of the Criminal Investigation Agency (Bareskrim) of Indonesia National Police (Polri). The formation of this agency is in response to the rise of special crimes that are far different from the types of general crimes known so far. In the special case, the perpetrators of the crimes are not uneducated people, but well-educated and intelligent people so that they can easily take advantage of internet technology to facilitate their criminal actions, which are commonly known as "White Collar Crimes." This crime has various types, ranging from economic and banking crimes, internet crimes, forestry and environmental crimes, corruption crimes, money laundering crimes, human trafficking crimes, to other types of crime that the Indonesian Criminal Code (KUHP) has not regulated yet. 
In the Criminal Procedural Code (KUHAP), one of the institutions authorized to conduct investigations and inquiry is the Indonesian National Police. In addition to the Criminal Procedure Code, the authority of the Indonesian National Police as investigators and inquirers to uncover criminal acts is also reaffirmed in Article 1 section 8 and 9, and Article 14, section (1) letter $\mathrm{g}$ of Law No. 2 of 2002 concerning the Indonesian National Police. The law states that one of the Indonesian National Police authorities is investigating and inquiring all criminal acts according to the criminal procedure code and other laws and regulations.

In dealing with special criminal cases, Directorate of Special Crimes was established by referring to the Regulation of the Indonesia National Police Chief number 22 of 2010 dated September 28, 2010, concerning the Organizational Structure and Work Procedure at the Regional Police. Specifically, it lies in article 10 letter g, which states that one of the elements implementing principal duties as referred to in Article 7 letter c is Directorate of Special Crimes. The authority of the police as investigators and inquirers is a manifestation of the primary duties of the police, as stated in Article 13 of Law No. 2 of 2002, namely to maintain security and public order; enforce the law, and provide protection and service to the community.

In dealing with special crimes, the investigator of the Directorate of Special Crimes must always synergize with other institutions that are related to the particular type of crimes they are handling [2]. For example, in the new Law of Prevention and Eradication of the Criminal Act of Money Laundering (UU PPTPPU), there is a fundamental change related to investigations, namely the granting of authority to investigators of the original criminal acts under the coordination of PPATK to conduct TPPU investigations related to the provenance of the criminal acts (for example, illegal logging) [3].

Strengthening the Role of the Directorate of Special Crimes of the Indonesian National Police in Terms of Special Criminal Law Enforcement

In light of the increasing special crimes, strengthening the existence of the Directorate of Special Crimes of the Indonesian National Police, covering the quality of the Investigators, must be continuously, comprehensively, and holistically held with the following approach:

1) Juridical Efforts:

- Coordinating with the Indonesia National Police and institutions incorporated in the Criminal Justice System (CJS) [4];

- Disclosing special criminal cases by taking advantage of advanced technology;

- Strengthening the investigators of the Directorate of Special Crimes by giving material expertise to investigate the perpetrators and witnesses, assess the evidence, and reconstruct crime scenes for the sake of accelerating the disclosure of special criminal cases.

- Organizing socialization to give the public an understanding of the types of special crime.

2) Technical Efforts

- Coaching the mental attitude and courage of investigators in carrying out investigations of special crimes despite the vast challenge they should face in a case;

- Optimizing the duties of investigators and encouraging motivation and discipline in handling special criminal investigations [5];

- Participating in education and training on how to handle special criminal acts.

- Improving and equipping the investigator's knowledge and ability in the field of information technology and other technologies needed to handle technological crimes.

- Improving the quality of the facilities, infrastructure, and budget submissions as the investigators' performance supporter.

\section{Conclusion}


Strengthening the Directorate of Special Crimes of the Indonesian National Police must be continuously improved in terms of both the quality and quantity of the investigator. The institution also should be fully supported by the infrastructures supporting the investigators' performance in disclosing special criminal cases. Nowadays, the existence of the Directorate of Special Crimes of the Indonesian National Police is still necessary to answer the challenges of various special crimes that invariably evolve by following the rhythm of technological developments in this digital era.

\section{Acknowledgments}

The author would like to thank and give an appreciate to the Head of Semarang State University for providing a facility to join International Conference in ICILS 2020.

\section{References}

[1] M. F. Wardojo, "Kedudukan Komisi Pemberantasan Korupsi Sebagai Lembaga Negara," Leg. Standing J. Ilmu Huk., 2018.

[2] P. Ersan and A. Erliyana, "Kualifikasi Hukum Pidana Khusus Terhadap Tindak Pidana Pemilu/Pilkada," Pakuan Law Rev., vol. 4, no. 1, pp. 1-23, 2018.

[3] F. Firdaus, "Eksistensi Penyidik Pegawai Negeri Sipil (Ppns) Dalam Struktur Pemerintahan Daerah," Din. Huk., 2013.

[4] H. Thalib, A. Ramadhan, and H. Djanggih, "The Corruption Investigation In The Regional Police of Riau Islands, Indonesia," Rechtsidee, 2017.

[5] A. H. Limbong, "Kendala dalam Penyidikan terhadap Tindak Pidana Pencucian Uang (Studi di Kepolisian Daerah Jawa Timur)," Kumpul. J. Mhs. Fak. Huk., vol. 1, no. 8, 2014. 